\title{
DELAÇÃO PREMIADA: O VALOR PROBATÓRIO NO PROCESSO PENAL
}

\author{
Mariana Ghizoni ${ }^{1}$ \\ Klauss Corrêa de Souza ${ }^{2}$ \\ Fábio Gesser Leal ${ }^{3}$
}

\section{RESUMO}

O presente artigo objetiva analisar o valor probatório da delação premiada no processo penal brasileiro. Utilizando-se do método de pesquisa qualitativo e de revisão bibliográfica e jurisprudencial, inicialmente far-seá um breve escorço histórico acerca da origem do instituto, de acordo com a legislação americana e italiana, que serviram de inspiração ao legislador pátrio. Na sequência, serão objeto de investigação as previsões normativas da colaboração processual no ordenamento jurídico brasileiro, a conceituação e a sua natureza jurídica, bem como os requisitos mínimos legais previstos para a sua admissibilidade. A fim de possibilitar melhor compreensão, abordar-se-ão as questões que permeiam a prova no processo penal, desde a sua delimitação conceitual até a atividade de valoração processual. Em ato contínuo, a partir de uma análise das aferições internas e externas da prova, discorrer-se-á a respeito do valor probatório da delação premiada no Brasil, à luz da regra de corroboração. Em arremate, tratar-se-á de algumas problemáticas que gravitam em torno do instituto: a (in)constitucionalidade e a questão ética em face da delação premiada. Encerra-se o presente desenvolvimento com a conclusão de que a delação possui valor probatório, podendo, efetivamente, ser utilizada como meio de obtenção de prova para sustentar o édito condenatório de terceiros, desde que, submetida ao crivo do contraditório e da ampla defesa, encontre respaldo nos demais elementos de prova reunidos no processo penal.

Palavras-chave: Delação premiada. Prova. Valor probatório. Processo penal.

\section{PLEA BARGAINING: THE PROBATIVE VALUE IN THE CRIMINAL PROCEDURE}

\section{ABSTRACT}

The present article aims to analyze the probative value of the plea bargaining the Brazilian criminal procedure. Using the qualitative research method and a bibliographical and jurisprudential review, initially, will be made a brief history of the origin of the institute in Comparative Law, with a view to American and Italian legislation, which served as a source of inspiration for the country's legislature. Subsequently, will be investigated the normative forecasts of the procedural collaboration in this legal system, the concept and the legal nature, as well as the general requirements for its legal admissibility. In order to provide a better understanding, the questions that pervade the evidence in the criminal procedure, from its conceptual delimitation to the procedural valuation activity, will be addressed. On the basis of an analysis of the internal and external assessments of the evidence, we will discuss the probative value of the plea bargaining in Brazil, in light of the rule of procedural corroboration. In closing, it will deal with some issues that gravitate around the institute: (in)constitutionality and

\footnotetext{
${ }^{1}$ Pós-graduanda em Direito Penal. Graduada em Direito pelo Centro Universitário Barriga Verde - UNIBAVE. Assessora jurídica na Justiça de $1^{\circ}$ Grau em Santa Catarina. E-mail: mariana.ghizoni@tjsc.jus.br ou marianaghizoni@hotmail.com.

${ }^{2}$ Mestre em Ciência Jurídica pela Universidade do Vale do Itajaí (Univali). Dupla Titulação de Mestrado em Direito pela Universitat d'Alacant (UA). Pós-graduação em nível de Especialização em Direito e Gestão Judiciária para Magistrados pela Universidade Federal de Santa Catarina (UFSC). Graduado em Direito pela Universidade do Sul de Santa Catarina (UNISUL). Professor da Universidade do Sul de Santa Catarina (UNISUL) e da Fundação Educacional Barriga Verde (FEBAVE). Juiz de Direito em Santa Catarina. E-mail: klauss@tjsc.jus.br.

${ }^{3}$ Mestrando em Direito pela Universidade do Extremo Sul Catarinense - UNESC. Especialista pela Universidade do Sul de Santa Catarina - UNISUL, em parceria com a Rede de Ensino Luiz Flávio Gomes - LFG. Graduado em Direito e em Administração de Empresas pelo Centro Universitário Barriga Verde - UNIBAVE. Professor titular na UNISUL. Assessor de Gabinete na Justiça Estadual de $1^{\circ}$ Grau em Santa Catarina. E-mail: fabiogesserleal@tjsc.jus.br.
}

Rev. do Cejur: Prestação Jurisdicional, Florianópolis v.7 n.1, p.39-60, Janeiro-Dezembro. 2019. 
the ethical issue in the face of the plea bargaining. The present development is concluded with the conclusion that the evidence has a probative value, and can effectively be used as a means of obtaining evidence to support the condemnatory edict of third parties, provided that, subject to the sifting of the adversary and the defense, find support in the other evidence gathered in criminal proceedings.

Keywords: Plea bargaining. Evidence. Probative value. Criminal procedure.

\section{INTRODUÇÃO}

O presente artigo dedica-se ao estudo da delação premiada, instituto que vem estampando os noticiários do Brasil de maneira assídua nos últimos anos e provocando acentuadas discussões doutrinárias, acadêmicas e jurisprudenciais a respeito do tema. Tal celeuma dá-se, sobretudo, porque a delação premiada é, em apertada síntese, um acordo celebrado entre o Estado e o infrator, a fim de que este, além de confessar a autoria de um fato criminoso, atribua a terceiro(s) a participação na atividade ilícita, em troca de benefícios penais.

Daí, portanto, deriva a indagação que serviu de "mola propulsora" principal ao objeto de pesquisa em tela: a delação premiada, utilizando-se das palavras de um traidor, pode servir de meio probatório para embasar a condenação do comparsa delatado?

Nessa ambiência, dada a importância da delação premiada no atual contexto político, jurídico e social em que vive o país, busca-se investigar o valor probatório da delação premiada no processo penal brasileiro, à luz das garantias processuais, e, assim, o modelo de justiça penal negocial adotado no Brasil. Procede-se, inicialmente, à análise do contexto histórico do direito premial no ordenamento estrangeiro, de acordo com a legislação americana e italiana, que serviram de principal inspiração ao legislador pátrio.

$\mathrm{Na}$ sequência, serão objeto de investigação as previsões normativas da colaboração processual no ordenamento jurídico brasileiro, a sua conceituação e natureza jurídica, bem como os requisitos mínimos legais previstos para a sua admissibilidade. Também serão abordados os aspectos gerais que circundam a prova no processo penal, a partir de uma análise conceitual, e o curso do atual sistema de valoração de provas. 
Por fim, adentrar-se-á no ponto nevrálgico do presente estudo: o valor probatório da delação premiada no processo penal, mediante uma análise das aferições internas e externas do meio de obtenção de prova. Em arremate, embora sem esgotar o tema com a profundidade necessária, apresentar-se-á ao leitor duas problemáticas que permeiam a colaboração processual no Brasil: a (in)constitucionalidade e a questão ética.

O tema, além de instigante e provocador, é por demais espinhoso, visto que não se encontra inserido de forma ordenada e uniforme no ordenamento jurídico brasileiro, tampouco pacificado em nossos tribunais.

\section{BREVE ESCORÇO HISTÓRICO A RESPEITO DA DELAÇÃO PREMIADA NO DIREITO ESTRANGEIRO: ESTADOS UNIDOS DA AMÉRICA E ITÁLIA}

A história da humanidade exibe diversas passagens em que a traição imperou entre os homens. Conforme lembra Renato Brasileiro de Lima (2015, p. 759): “Judas Iscariotes vendeu Cristo pelas célebres 30 (trinta) moedas; Joaquim Silvério dos Reis denunciou Tiradentes, levando-o à forca; Calabar delatou os brasileiros, entregando-os aos holandeses".

Com o desenvolvimento das sociedades e a formação de agrupamentos para a prática de ilícitos (as ditas organizações ou associações criminosas), a atividade de "barganha" ou "negociata penal" logrou espaço nos ordenamentos mais modernos (LIMA, 2015, p. 759).

Heráclito Antônio Mossin e Júlio César O. G. Mossin (2016, p. 37) asseguram que o instituto "teve seu nascedouro nas Ordenações Filipinas (1603), também denominada de Código Filipino, as últimas da legislação portuguesa, que preponderaram até a entrada em vigor do Código Criminal de 1830".

Conquanto já estivesse ali inserta a concessão de perdão aos delatores que entregassem seus comparsas ao rei, inexistia a denominação "delação premiada", que ganhou espaço, sobretudo, nas legislações americana e italiana, inspiradoras do modelo negocial penal implantado no Brasil (MOSSIN; MOSSIN, 2016, p. 37).

De um acurado exame da origem histórica da delação no direito estrangeiro, Adalberto José Q. T. de Camargo Aranha preleciona que: 
A delação premiada teria surgido nos Estados Unidos no decorrer da campanha contra a Máfia, a Cosa Nostra e outras organizações criminosas, quando, por via de uma transação de natureza penal, firmada pelos Procuradores Federais e alguns suspeitos de militância criminosa, a estes era prometida a impunidade desde que confessassem sua participação e prestassem informações que fossem suficientes para atingir toda a organização e seus membros. Estes últimos, além de confessarem sua participação criminosa, prestavam as informações necessárias para o envolvimento, prisão e condenação dos outros participantes (ARANHA, 2008, p. 136).

No que tange aos procedimentos jurídicos desenvolvidos, verifica-se que, no sistema processual penal dos Estados Unidos da América, a delação premiada fora implementada por meio da ferramenta denominada "plea bargaining" (SANTOS, 2017, p. $33)$.

Acerca do modelo americano, Marcos Paulo Dutra Santos (2017, p. 37) assevera que lá "o réu possui, em geral, três alternativas: declarar-se expressamente culpado [...], afirmar que não contesta a acusação, sem, no entanto, assumir a culpa [...], ou declarar-se inocente".

Tal técnica processual justifica-se, sobretudo, porque nos Estados Unidos da América vigora o princípio da discricionariedade, de modo que ao promotor de justiça é dado o livre convencimento a respeito da necessidade ou não do exercício da ação penal.

Importa destacar que não há, no sistema jurídico processual americano, requisitos objetivos para a realização da delação premiada por meio da "plea bargaining”, porquanto "qualquer réu pode negociar com a promotoria a sua pena, pouco importando seus antecedentes ou o teor da imputação delituosa que lhe é dirigida" (SANTOS, 2017, p. 40).

Exige-se, contudo, para a validação da colaboração processual como meio de obtenção de prova, a existência de (a) livre manifestação de vontade do réu e (b) plena capacidade para o exercício dos atos da vida civil, de maneira a assegurar que o delator tenha total consciência do pacto que está celebrando e das garantias processuais abdicadas.

Outrossim, a análise da validade da colaboração no sistema americano perpassa por um controle de corroboração com os demais elementos de informação colhidos nos autos, de sorte que "antes de referendar a declaração de culpa do acusado, condenando-o, o juízo verifica se existe suporte probatório para tanto [...]. Se negativa a resposta, rejeitará o negócio pactuado entre a promotoria e a defesa" (SANTOS, 2017, p. 51).

Já na Itália, a delação premiada notabilizou-se a partir de 1970, quando se procurou desenvolver mecanismos de combate ao terrorismo e à extorsão mediante sequestro. 
No entanto, fora nos idos de 1980 que o instituto de direito premial alcançou seu apogeu, quando, por meio da "Operação Mãos Limpas", explorou-se em demasia a técnica a fim de desmantelar-se a Máfia (MOSSIN; MOSSIN, 2016, p. 32-33).

No modelo da Itália, porém, denota-se maior ousadia do Estado, alargando-se as vias da negociata penal, pois há "um modelo em que é possível o órgão acusador e o imputado empreenderem negociação a fim de abreviar o procedimento penal. Essa transação penal acerca do rito procedimental é chamada de patteggiamento" (GONZALEZ, 2010, p. 18).

Apesar das similaridades, a técnica italiana diferencia-se da americana, em especial, pela aplicação restrita e direcionada aos líderes das organizações criminosas, de sorte que o "patteggiamento" não se reserva a qualquer crime ou acusado (SANTOS, 2017, p. 66).

No sistema processual italiano, ademais, permite o instituto premial "que o réu e o Ministério Público transijam não só sobre a reprimenda a ser aplicada, mas também quanto ao procedimento a ser adotado. Negociam-se a pena e o rito" (SANTOS, 2017, p. 59).

Quanto ao controle de legalidade exercido pelo Judiciário italiano acerca da negociata penal, Marcos Paulo Dutra Santos (2017, p. 67) preleciona que o juiz "pode acolher o patteggiamento, apesar da oposição do Ministério Público, mas a partir do requerimento formulado pelo imputado. [...] Rejeitado o patteggiamento, restabelece-se ao Ministério Público o direito de ação".

No que concerne à validação da delação premiada como meio de obtenção de prova, à semelhança do modelo americano, o Juízo italiano apenas a chancela se existir lastro probatório mínimo nos autos a embasar a imputação delitiva realizada pelo delator.

\section{DA PREVISÃo LEgal dA DELAÇÃo PREMIAda NO ORDENAMENTO JURÍDICO BRASILEIRO}

O instituto da delação premiada encontra-se amplamente difundido no ordenamento brasileiro, mas não recebeu tratamento uniforme e ordenado pelo legislador pátrio.

O primeiro regramento no Brasil a disciplinar expressamente a possibilidade de concessão de premiação àquele que colabora com a Justiça, "entregando" os demais comparsas e possibilitando a dissolução da organização criminosa, data do ano de 1990,

Rev. do Cejur: Prestação Jurisdicional, Florianópolis v.7 n.1, p.39-60, Janeiro-Dezembro. 2019. 
quando, por meio da Lei de Crimes Hediondos (Lei $n^{\circ} 8.072 / 90$ ), especialmente o artigo $8^{\circ}$, parágrafo único, definiu-se que "o participante e o associado que denunciar à autoridade o bando ou quadrilha, possibilitando seu desmantelamento, terá a pena reduzida de um a dois terços" (BRASIL, 1990).

Como diploma normativo geral a regulamentar a delação premiada no direito positivo brasileiro, desponta a Lei de Proteção a Vítimas e a Testemunhas (Lei nº 9.807/99), que foi pioneira em estabelecer a previsão legal da concessão de perdão judicial e extinção da punibilidade ao delator. $\mathrm{O}$ regramento específico de tal benesse encontra-se esculpido nos artigos 13 e 14 da legislação supracitada, consoante se destaca ipsis litteris:

Art. 13. Poderá o juiz, de ofício ou a requerimento das partes, conceder o perdão judicial e a conseqüente extinção da punibilidade ao acusado que, sendo primário, tenha colaborado efetiva e voluntariamente com a investigação e o processo criminal, desde que dessa colaboração tenha resultado: I - a identificação dos demais co-autores ou partícipes da ação criminosa; II - a localização da vítima com a sua integridade física preservada; III - a recuperação total ou parcial do produto do crime. Parágrafo único. A concessão do perdão judicial levará em conta a personalidade do beneficiado e a natureza, circunstâncias, gravidade e repercussão social do fato criminoso.

Art. 14. O indiciado ou acusado que colaborar voluntariamente com a investigação policial e o processo criminal na identificação dos demais coautores ou partícipes do crime, na localização da vítima com vida e na recuperação total ou parcial do produto do crime, no caso de condenação, terá pena reduzida de um a dois terços. (BRASIL, 1999).

Além da referida norma geral (Lei $n^{\circ}$ 9.807/99) e da Lei de Crimes Hediondos (Lei $\mathrm{n}^{\circ}$ 8.072/90, artigo $8^{\circ}$, parágrafo único), estão vigentes no atual ordenamento jurídico brasileiro outras sete hipóteses legais que contemplam o instituto da colaboração premiada, a saber: (1) Lei dos Crimes contra o Sistema Financeiro Nacional (Lei n ${ }^{\circ} 7.492 / 86$, artigo 25, § $2^{\circ}$, com redação dada pela Lei ${ }^{\circ}$ 9.080/95); (2) Lei dos Crimes contra a Ordem Econômica e Tributária (Lei $\mathrm{n}^{\circ}$ 8.137/90, artigo 16, parágrafo único, com redação dada pela Lei $\mathrm{n}^{\circ}$ 9.080/95); (3) crime de extorsão mediante sequestro, previsto no artigo 159, § $4^{\circ}$, do Código Penal, com redação dada pela Lei $n^{\circ}$ 9.269/96; (4) Lei de Drogas (Lei n ${ }^{\circ} 11.343 / 06$, artigo 41); (5) Lei de Crimes de Formação de Cartel ou Lei Antitruste (Lei n ${ }^{\circ}$ 12.529/2011, artigos 86 e 87); (6) Lei de Lavagem de Capitais (Lei ${ }^{\circ} 9.613 / 98$, artigo $1^{\circ}$, $\S 5^{\circ}$, com redação dada pela Lei $n^{\circ} 12.683 / 12$ ) e (7) Lei de Organizações Criminosas (Lei $n^{\circ} 12.850 / 13$, artigo $4^{\circ}$ ) (SANTOS, 2017, p. 115). 
Nesse cenário, merece destaque a Lei $\mathrm{n}^{\circ}$ 12.850/13 (Lei de Organizações Criminosas), a qual, por se tratar do último diploma normativo produzido no Brasil a contemplar a aplicação da delação premiada, recebeu tratamento mais pormenorizado pelo legislador, haja vista a existência de determinado procedimento próprio, com a previsão de uma seção em seu capítulo II a abordar o tema (do artigo $4^{\circ}$ ao artigo $7^{\circ}, \S 3^{\circ}$ ), ainda que intitulado sob a denominação "colaboração premiada".

Consta do artigo $4^{\circ}$ da Lei $n^{\circ} 12.850 / 13$ :

Art. 4 $\mathrm{O}$ juiz poderá, a requerimento das partes, conceder o perdão judicial, reduzir em até $2 / 3$ (dois terços) a pena privativa de liberdade ou substituí-la por restritiva de direitos daquele que tenha colaborado efetiva e voluntariamente com a investigação e com o processo criminal, desde que dessa colaboração advenha um ou mais dos seguintes resultados: I - a identificação dos demais coautores e partícipes da organização criminosa e das infrações penais por eles praticadas; II - a revelação da estrutura hierárquica e da divisão de tarefas da organização criminosa; III - a prevenção de infrações penais decorrentes das atividades da organização criminosa; IV - a recuperação total ou parcial do produto ou do proveito das infrações penais praticadas pela organização criminosa; V - a localização de eventual vítima com a sua integridade física preservada. (BRASIL, 2013).

Ao analisar a hipótese de previsão normativa de colaboração premiada disposta na

Lei $\mathrm{n}^{\circ}$ 12.850/13, Renato Brasileiro de Lima elucida que tal regramento passa:

A conferir mais eficácia à medida sob comento, seja por regulamentar expressamente a celebração do acordo de colaboração premiada, dispondo sobre a legitimidade para a proposta, conteúdo do acordo e necessária homologação judicial, seja por prever expressamente que nenhuma sentença condenatória poderá ser proferida com fundamento apenas nas declarações do colaborador. (LIMA, 2015, p. 768-769).

Nesse panorama, é de se notar que, diante de uma vasta gama de leis a abordarem o mesmo instituto jurídico, não rara é a possibilidade de conflito aparente de normas.

De acordo com os critérios de resolução de antinomia jurídica consagrados por Norberto Bobbio, destaca-se, no plano geral de aplicabilidade da matéria, isto é, como o diploma legal geral sobre o assunto, a Lei no 9.807/99 (Lei de Proteção a Vítimas e Testemunhas). Depois dessa, exibe-se como lei mais geral sobre delação premiada a Lei $\mathrm{n}^{\circ}$ 8.072/90 (Lei de Crimes Hediondos), por tratar de gêneros de crimes, e não somente de um único tipo legal (SANTOS, 2017, p. 116). 
Em qualquer situação, porém, deve prevalecer a aplicação do instituto com base no critério da especialidade, de maneira que as especificidades da norma mais especial sobre o tema façam preteridas as regras da norma mais geral. Essa é a orientação que prevalece, inclusive salientando o perfeito convívio da Lei n. 12.850/13 com as demais leis sobre delação premiada (SANTOS, 2017, p. 115-116).

Não se ignora, apesar disso, a existência de opinião segundo a qual:

Diante desse anárquico quadro legislativo, [...] em face das garantias da irretroatividade da lei penal mais grave e da retroatividade da lei penal mais favorável (art. $5^{\circ}, \mathrm{XL}$, da CR), deverá o juiz, em cada caso concreto, aplicar a lei que seja mais benéfica ao acusado. Se houver dúvida sobre qual delas o seja, deverão o acusado e seu defensor ser consultados, em face do princípio do favor libertatis (DELMANTO; DELMANTO JUNIOR; DELMANTO, 2014, p. 1.006, grifo dos autores).

No mais, conquanto persista no ordenamento jurídico brasileiro variados diplomas normativos a tratarem da hipótese de delação premiada indistintamente e sem qualquer sistematização ou integração, Gilson Dipp destaca um importante ponto de interseção entre as previsões legais:

A principal marca da disciplina legal relativa a essa forma de colaboração nos diferentes regramentos é que ela se refere sempre a crimes praticados por mais de um agente em forma de coautoria ou coparticipação, ou de organização criminosa ou quadrilha ou bando, de modo a deixar assente que a delação ou colaboração não se aplica aos casos de crimes individuais ou sem a característica de grupo, bando, quadrilha ou organização voltada para o crime (DIPP, 2015, p. 17, grifo do autor).

\section{DA CONCEITUAÇÃO E NATUREZA JURÍDICA DO INSTITUTO DA DELAÇÃO PREMIADA}

Consoante ensina Deonísio da Silva (2014, p. 136), a palavra “delação” origina-se do latim "delatione" e designa "ato de entregar". Guilherme de Souza Nucci (2014, p. 422) assim complementa a definição: “delatar significa acusar, denunciar ou revelar".

Adalberto José Q. T. de Camargo Aranha conceitua o instituto:

A delação, ou chamamento de co-réu, consiste na afirmativa feita por um acusado, ao ser interrogado em Juízo ou ouvido na polícia, e pela qual, além 
de confessar a autoria de um fato criminoso, igualmente atribuiu a um terceiro a participação como seu comparsa (ARANHA, 2008, p. 132).

A premiação, por sua vez, pode consistir em diminuição da reprimenda penal em até $2 / 3$ ou mesmo no perdão ministerial ou judicial, culminando tanto na possibilidade do não oferecimento da denúncia quanto na própria extinção da punibilidade do delator, haja vista a vasta gama de legislações esparsas no ordenamento jurídico brasileiro a disciplinarem a possibilidade de colaboração processual.

Noutra senda, cumpre esclarecer, quanto à existência da dualidade nominativa do instituto ("colaboração" ou "delação" premiada), que há divergência na doutrina brasileira a respeito do termo técnico adequado, sobretudo porque o legislador não adotou uma denominação única ao longo da produção legiferante sobre o tema.

Nesse cenário, Renato Brasileiro de Lima (2015, p. 761) defende que as expressões não são sinônimas, uma vez que a colaboração premiada é dotada de maior abrangência:

O imputado, no curso da persecutio criminis, pode assumir a culpa sem incriminar terceiros, fornecendo por exemplo, informações acerca da localização do produto do crime, caso em que é tido como mero colaborador. Pode, de outro lado, assumir a culpa (confessar) e delatar outras pessoas nessa hipótese é que se fala em delação premiada (ou chamamento de corréu). Só há falar em delação se o investigado ou acusado também confessa a autoria da infração penal (LIMA, 2015, p. 761, grifo do autor).

Diante desse quadro, considerando-se a existência de possível instituto processual mais abrangente que a delação e, portanto, distinto em certas peculiaridades, adverte-se, desde já, que o presente artigo destina-se exclusivamente a analisar a delação premiada e seus aspectos jurígenos no âmbito do processo penal, com vistas à investigação do valor probatório como meio de obtenção de prova.

No que concerne à natureza jurídica do instituto da delação premiada, destaca-se, a princípio, que não pode ser entendida como confissão (ARANHA, 2008, p. 133) nem guarda relação com a prova testemunhal.

O Supremo Tribunal Federal, ao analisar a matéria de direito premial, já assentou que:

A colaboração premiada é um negócio jurídico processual, uma vez que, além de ser qualificada expressamente pela lei como "meio de obtenção de

Rev. do Cejur: Prestação Jurisdicional, Florianópolis v.7 n.1, p.39-60, Janeiro-Dezembro. 2019. 
prova", seu objeto é a cooperação do imputado para a investigação e para o processo criminal, atividade de natureza processual, ainda que se agregue a esse negócio jurídico o efeito substancial (de direito material) concernente à sanção premial a ser atribuída a essa colaboração (STF, 2015, HC 127.483/PR, grifo nosso).

Na doutrina, entretanto, verificam-se, mais uma vez, posições divergentes quanto ao assunto, haja vista que, ora, parte dos juristas compreende ser a delação "meio" de prova, ora, "espécie" de prova inominada anômala.

Renato Brasileiro de Lima (2015, p. 778), imprimindo ao instituto natureza de ordem processual, por compreender tratar-se de um "meio" e não do "fim" a que se destina, consigna que "a colaboração premiada funciona como importante técnica especial de investigação, enfim, um meio de obtenção de prova".

Em sentido diverso, Paulo Quezado Jamile Virgino (2009 apud LIMA, 2015, p. 778) aduz "tratar-se a delação de verdadeira prova anômala, inominada, pois não arrolada no CPP; um testemunho impróprio [...]".

Adalberto José Q. T. de Camargo Aranha (2008, p. 132), por sua vez, também se filia à ideia sobredita, ao apregoar que a delação premiada é "uma prova anômala, admissível e sem qualquer previsão ou regulamentação legal".

Já Marcos Paulo Dutra Santos, ao enfrentar a questão, fazendo menção à decisão assentada pelo Supremo Tribunal Federal outrora colacionada, acrescenta que:

A colaboração premiada, em si, é veículo de produção probatória, porquanto, a partir das informações disponibilizadas, deflagram-se diligências em busca de provas que as endossem. As declarações do delator, por sua vez, consubstanciam meio de prova. Em termos probatórios, é imprescindível fazer um corte, separando a cooperação em si - instrumento de formação de provas - do depoimento fornecido - meio de prova (SANTOS, 2017, p. 85, grifo do autor).

\section{DOS REQUISITOS PARA A REALIZAÇÃO DA DELAÇÃO PREMIADA}

Para que a colaboração processual do corréu consubstancie o fim almejado pelo colaborador, qual seja, a obtenção dos prêmios legais, faz-se necessário que se preencham alguns requisitos previamente estabelecidos. Abaixo, serão expostos, pois, os requisitos gerais ou requisitos mínimos legalmente fixados para que se possa adotar qualquer delação, apurados com base no exame dos diversos diplomas que tratam da temática.

Rev. do Cejur: Prestação Jurisdicional, Florianópolis v.7 n.1, p.39-60, Janeiro-Dezembro. 2019. 
Dentre os pressupostos para o reconhecimento do negócio jurídico premial, em primeiro lugar desponta a necessidade da existência da autoria ou participação de mais de um infrator, na medida em que, essencialmente, a delação se presta a revelar delito(s) cometido(s) por mais de um agente, seja em forma de coautoria, coparticipação ou, ainda, organização criminosa, quadrilha ou bando.

O segundo requisito consiste na exigência de voluntariedade, isto é, na vontade livre e consciente do agente em contribuir com a Justiça, tal qual se verifica na seara civil, em nítida similaridade com a celebração contratual.

Cumpre esclarecer, ademais, que a voluntariedade não se confunde com a espontaneidade, ou seja, com ato cuja iniciativa nasce diretamente da vontade do delator. Assim, ainda que parte da legislação vigente no Brasil faça menção à necessidade de a delação ser espontânea, Renato Brasileiro de Lima (2015, p. 770) assegura que "prevalece o entendimento de que a espontaneidade não é condição sine qua non para a aplicação dos prêmios legais inerentes a colaboração premiada".

Verifica-se, deste modo, plenamente possível que a delação premiada seja proposta por terceiros, como pelo Ministério Público, quer na etapa policial ou judicial, ou ainda, pelo delegado de polícia ou defensor do ora investigado/denunciado.

Desvela-se inadmissível, no entanto, a existência de coação (física ou psíquica), violência ou qualquer meio de persuasão do delator, o que, invariavelmente, conduz à invalidade da prova, por ser tamanha a afronta aos preceitos constitucionais (art. $5^{\circ}$, inciso LVI, da Constituição da República Federativa do Brasil de 1988).

Por derradeiro, o terceiro e último requisito indispensável a ser observado para que o colaborador faça jus aos benefícios legais reside na "relevância e eficácia objetiva das declarações prestadas pelo colaborador” (LIMA, 2015, p. 771), de modo que a delação só será chancelada se as informações trazidas pelo agente efetivamente possibilitarem a obtenção de provas da materialidade do crime e da autoria e/ou participação do(s) comparsa(s) delatado(s).

Vale consignar, à guisa do exposto por Renato Brasileiro de Lima (2015, p. 771), que, "na hipótese de colaboração realizada na fase extrajudicial, ela deve ser mantida pelo colaborador em juízo. Se houver retratação, não é possível a concessão do prêmio legal”. Nesse sentido, já decidiu o Superior Tribunal de Justiça (STJ, 2010, HC 120.4554/RJ).

Em suma, podem-se elencar como requisitos gerais à obtenção da premiação pela colaboração com a Justiça: (a) a existência de crime praticado por mais de um autor ou partícipe; (b) a voluntariedade; (c) a eficácia da colaboração prestada. 
No entanto, é curial salientar que, por existirem, atualmente, nove diplomas normativos vigentes distintos com tratamento da matéria, cada qual mantém suas próprias peculiaridades, de modo que, como dito alhures, os pressupostos acima descritos representam apenas os de aplicabilidade geral, sendo devido, no que concerne aos requisitos de aplicabilidade específica, investigar qual a legislação a ser efetivamente aplicada no caso concreto, a fim de perquirir acerca da existência de pressuposto especializado a ser observado.

\section{DA PROVA NO PROCESSO PENAL}

No desiderato de atingir o objetivo proposto no presente estudo, exibe-se curial um estudo básico da prova no âmbito processual penal, o que se passa a fazer.

\section{1 Do Conceito de Prova}

O termo "prova" é plurívoco, ou seja, dotado de diversas acepções, entre as quais as ideias de verificação, inspeção, exame, confirmação. Dele deriva o verbo "provar", que significa verificar, examinar, reconhecer por experiência (LIMA, 2015, p. 571).

Edilson Mougenot Bonfim (2015, p. 407) define que "prova é o instrumento usado pelos sujeitos processuais para comprovar os fatos da causa, isto é, aquelas alegações que são deduzidas pelas partes como fundamento para o exercício da tutela jurisdicional”.

Outrossim, Renato Brasileiro de Lima (2015, p. 572) destaca que "a palavra prova só pode ser usada para se referir aos elementos de convicção produzidos, em regra, no curso do processo judicial e, por conseguinte, com a necessária participação dialética das partes". Trata-se da prova produzida sob o manto do contraditório e da ampla defesa.

Já os elementos de prova "são aqueles colhidos na fase investigatória, sem a necessária participação dialética das partes” (LIMA, 2015, p. 572). São elementos de informação, os quais, em regra, são produzidos sem a observância do contraditório e da ampla defesa.

\section{2 Do Objeto e Finalidade da Prova}

Rev. do Cejur: Prestação Jurisdicional, Florianópolis v.7 n.1, p.39-60, Janeiro-Dezembro. 2019. 
Impende gizar que "todos os fatos deixam vestígios, que podem ser reais ou morais. Os primeiros ligam-se à realidade inconsciente das coisas, enquanto os segundos resultam de impressões conscientes do espírito" (ARANHA, 2008, p. 25).

Nesse seguimento, Paulo Rangel (2015, p. 462) ensina que “o objeto da prova é a coisa, o acontecimento que deve ser conhecido pelo juiz, a fim de que possa emitir um juízo de valor. São os fatos sobre os quais versa o caso penal".

Na busca pela verdade, portanto, destaca-se que o objeto da prova reside na (re)construção oral, documental, testemunhal ou por quaisquer outros meios do fato sub judice, a fim de permitir ao julgador conhecer o caso sobre o qual incidirá o direito.

\section{3 Da Fonte de Prova, Meios de Prova e Meios de Obtenção de Prova}

Renato Brasileiro de Lima (2015, p. 577) preleciona que "a expressão fonte de prova é utilizada para designar as pessoas ou coisas das quais se consegue a prova, daí resultando a classificação em fontes pessoais [...] e fontes reais [...]”.

As fontes pessoais de prova correspondem às origens subjetivas da veracidade dos fatos, relacionadas às pessoas do réu, vítima, testemunhas, etc., ao passo que as fontes reais consistem nos vestígios físicos da infração, tais quais documentos e objetos do crime.

No que tange ao meio de prova, pode ser definido como "todo fato, documento ou alegação que possa servir, direta ou indiretamente, à busca da verdade real dentro do processo" (BONFIM, 2015, p. 411-412). "São os instrumentos através dos quais as fontes de prova são introduzidas no processo" (LIMA, 2015, p. 577).

A título de exemplificação da diferença existente entre fonte e meio de prova, Lima (2003 apud BADARÓ, 2015, p. 577) afirma que "a testemunha de um fato é a fonte de prova, enquanto suas declarações em juízo são o meio de prova. O documento é uma fonte de prova, a sua incorporação ao processo é o meio de prova".

Salienta-se, ademais, que os meios de prova podem ser lícitos ou ilícitos. Contudo, somente os primeiros são admitidos no processo, de acordo com a dicção legal contida nos artigos 5º inciso LVI, da Constituição Federal de 1988 e 157 do Código de Processo Penal.

Por derradeiro, os meios de obtenção de prova consistem em "certos procedimentos (em regra, extraprocessuais) regulados por lei, com o objetivo de conseguir provas materiais, e que podem ser realizados por outros funcionários que não o juiz (v.g.,

Rev. do Cejur: Prestação Jurisdicional, Florianópolis v.7 n.1, p.39-60, Janeiro-Dezembro. 2019. 
policiais)" (LIMA, 2015, p. 577). Servem de exemplo a interceptação telefônica e a infiltração de agentes.

\section{4 Da Valoração da Prova no Processo Penal}

A verdade material que se persegue ao longo do processo tem seu ponto culminante no sistema de avaliação da(s) prova(s) pelo julgador, o qual se utiliza de um conjunto de determinados critérios legais sistematizados para a formação de seu convencimento.

Adalberto José Q. T. de Camargo Aranha (2008, p. 78) aduz que "a avaliação da prova é um ato eminentemente pessoal do juiz, somente seu, mediante o qual, examinando, pesando e estimando os elementos oferecidos pelas partes, chega a uma conclusão sobre o alegado".

Atualmente, é adotado pelo ordenamento brasileiro o sistema de persuasão racional ou do livre convencimento motivado, que se refere à "obrigatoriedade de fundamentar e motivar a decisão para que se saiba quais as condicionantes que levaram o julgador à convicção dos fatos, para se aquilatar o acerto ou não da apreciação feita" (ARANHA, 2008, p. 82).

Dessarte, verifica-se inexistirem limites e regras abstratas de valoração, mas tampouco há a possibilidade de formar-se a convicção sem fundamentá-la (LOPES JR., 2015, p. 377).

A própria Constituição Federal exige em seu artigo 93, inciso IX, que todos os julgamentos dos órgãos do Poder Judiciário sejam públicos, e fundamentadas todas as decisões, sob pena de nulidade.

Contudo, a grande celeuma que gravita em torno do sistema de livre convencimento reside exatamente no limite dessa "liberdade" dada ao julgador. Daí porque Gomes Filho (2008 apud LIMA, 2015, p. 605) ensina que a liberdade na apreciação de provas não se confunde com uma autorização para que o julgador decida arbitrariamente, mas apenas lhe confere a possibilidade de fixar a verdade judicial com base em dados e critérios objetivos.

Alexandre de Morais da Rosa atenta para o fato de que:

Rev. do Cejur: Prestação Jurisdicional, Florianópolis v.7 n.1, p.39-60, Janeiro-Dezembro. 2019. 
As informações flutuam entre as pretensões de validade de modo que se empurram no sentido acusatório e/ou defensivo a todo o tempo, na incerteza do movimento, que não depende somente da forma e do conteúdo, mas fundamentalmente do arranjo narrativo. As colisões de sentido são intermitentes no jogo processual, e o desafio será compreender o passeio aleatório dos significantes probatórios (informação) a partir dos jogadores e do julgador que temos (e não o que imaginamos) (ROSA, 2017, on-line).

Logo, conclui-se, à guisa do exposto por Aury Lopes Jr. (2015, p. 873), em menção ao decisionismo de que trata Lenio Streck, que não se pode, jamais, permitir que o juiz possa dizer qualquer coisa sobre qualquer coisa, havendo limites para a decisão e para a interpretação.

\section{DO VALOR PROBATÓRIO DA DELAÇÃO PREMIADA: UMA ANÁlISE DAS AFERIÇÕES INTERNAS E EXTERNAS}

A ausência de um sistema processual ordenado e uniforme sobre a matéria provoca verdadeira insegurança jurídica, tanto para o agente que colabora - pois inexiste certeza sobre o procedimento a ser empregado, tampouco sobre como será premiada a sua colaboração e ainda como será valorado o conteúdo revelado - quanto para os demais sujeitos do processo, Ministério Público e juiz.

Adianta-se, a priori, que a doutrina e a jurisprudência asseguram, quase em sua totalidade, que, isoladamente, a delação premiada não se presta a sustentar um decreto condenatório (PEREIRA, 2009, p. 26).

O firme posicionamento sobredito advém da regra de corroboração, a qual exige "que o conteúdo da colaboração processual seja confirmado por outros elementos de prova" (BADARÓ, 2015, p. 28).

Neste sentido, a propósito, é a dicção do artigo $4^{\circ}, \S 16$, da Lei $n^{\circ} 12.850 / 13$, o qual preconiza que "nenhuma sentença condenatória será proferida com fundamento apenas nas declarações de agente colaborador".

Ressalta-se, todavia, que na fase investigatória, nada impede que uma colaboração premiada, tomada isoladamente, sirva como base para a instauração de um inquérito policial ou para o oferecimento de uma peça acusatória (LIMA, 2015, p. 779). Afinal, para a deflagração da persecução penal não se exigem elementos de certeza, mas apenas indícios de materialidade e de autoria da infração. 
As declarações tomadas do corréu ou partícipe devem ser valoradas a partir de duas perspectivas processuais básicas: (1) sob o manto dos elementos internos, subjetivos ou intrínsecos e (2) sob o prisma dos elementos externos, objetivos ou extrínsecos da prova.

Descortinam-se, neste contexto, como pressupostos internos para aferição do valor probatório da delação premiada,

A personalidade do colaborador e as relações que este mantinha com o delatado; os interesses não explicitados pelo delator (eventual intuito de vingança, suborno oferecido por organização oponente, etc.); existência de tentativa de eximir-se da real responsabilidade no ilícito investigado (GONZALEZ, 2010, p. 53).

Trata-se, em suma, de uma investigação preliminar acerca de quem é o delator, isto é, o corréu que, em troca de benefícios premiais próprios, trai seu(s) comparsa(s), lançando-o(s) às garras da tutela penal do Estado. Disso, portanto, deflui a averiguação da credibilidade do agente como importante pressuposto subjetivo a embasar (ou não) o valor da delação.

Já quanto à aferição externa do meio de obtenção de prova, Gonzalez (2010, p. 53-54) elenca como elementos extrínsecos "a coerência das declarações e a respectiva correspondência com elementos fáticos palpáveis, ou seja, ausência de evidências que desmintam as afirmações”.

Daí porque é remansoso o entendimento doutrinário e jurisprudencial de que "sem essa complementação probatória, restará contrariada a regra do art. $4^{\circ}, \S 16$, da Lei 12.850/13. A delação 'nua', isto é, sem um elemento de confirmação é, por si, inidônea para justificar uma condenação" (BADARÓ, 2015, p. 27).

Consoante bem explicita Frederico Valdez Pereira,

O delator precisa fornecer dados objetivos, consistentes em detalhes da atividade criminal declarada e que possam ser aferíveis prima facie como verossímeis e dignos de razoável aceitação nos primeiros contatos com os órgãos de investigação. Ausente isso, verificando-se tratar-se de mera acusação genérica despida de relato pormenorizado e de elementos concretos passíveis de futura comprovação, não se deve dar procedimento pela manifesta falsidade ou insubsistência objetiva do relato, que não possui $o$ intuito colaborativo [...] (PEREIRA, 2009, p. 31).

Outro importante aspecto acerca do valor probatório da delação reside na seguinte questão: tomando-se por indispensável a corroboração para alcançar o fim a que se destina o 
negócio jurídico processual, seria possível utilizar-se da colaboração de outrem para embasar a delação inicial?

Trata-se da hipótese de corroboração cruzada ou mutual corroboration, que é rechaçada em regra, pois "é insuficiente para o fim de corroboração [...] que o elemento de confirmação de uma delação premiada seja outra delação premiada, de um diverso delator, ainda que ambas tenham conteúdo concordante" (BADARÓ, 2015, p. 29).

Desse modo, não há que se falar em corroboração de delação premiada por meio de outra, ou com supedâneo em elementos esparsos angariados de outro delator, haja vista a necessidade de embasamento com os demais meios de prova em cada colaboração efetivamente prestada.

A questão do trato do valor probatório da delação premiada envolve uma aresta muito tênue na seara processual, a ponto de alertar-se para o fato de que:

Não se pode, no entanto, chegar à conclusão de que as declarações do colaborador não terão efeitos probatórios nenhum (sic). A opção feita pela ordem jurídica pátria em diversos dispositivos legais foi a de atribuir importância probatória à delação premiada, o que por certo não se resume à atribuição de simples efeito de notitia criminis. Não se pode chegar à distorção no caminho oposto de exigir que a comprovação dos fatos informados pelo delator estejam suficientemente demonstrados por outros meios de prova tradicionais, pois então esses outros elementos, por si só, esclareceriam os fatos, não havendo que se recorrer à colaboração processual (PEREIRA, 2009, p. 26).

Ademais, vale gizar que, fazendo-se necessária a oitiva, em juízo, do delator para esclarecimento de quaisquer dúvidas ou divergência sobrevindas em relação aos demais elementos de prova reunidos no processo, à guisa da regra da corroboração e "a fim de se lhe conferir o valor de prova, e não de mero elemento informativo, há de se assegurar a participação dialética das partes, respeitando-se o contraditório e a ampla defesa" (LIMA, 2015, p. 779, grifo do autor).

Advém daí, portanto, o cerne da questão que permeia o presente estudo: quando se poderá conferir às declarações do colaborador a força de derruir o direito fundamental à presunção de inocência do acusado no bojo do processo?

A resposta para o presente questionamento, que aqui não se esgota, por certo, exige uma análise do princípio da presunção de inocência, em face da constitucionalidade da delação premiada como meio de obtenção de prova. Para tanto, Frederico Valdez Pereira sintetiza que "uma das exigências para se conferir valor probatório às declarações do delator 
no processo, desfazendo-se o direito à presunção de inocência do acusado, é a necessidade de se submeter esse elemento de prova ao contraditório" (PEREIRA, 2009, p. 30).

A fim de que a delação possa servir de meio probatório para embasar futuro édito de condenação do comparsa delatado, verifica-se, portanto, imprescindível que o exercício do contraditório seja a este oportunizado.

Considerando-se, no entanto, tal premissa indispensável, é pertinente a indagação: "se ao atingido pela delação não é possível interferir no interrogatório do acusador, fazendo perguntas ou reperguntas que poderão levar à verdade ou ao desmascaramento, onde é obedecido o princípio do contraditório?” (ARANHA, 2008, p. 136).

Para o renomado jurista Adalberto José Q. T. de Camargo Aranha, que entende ser a delação premiada prova anômala em si mesma e não um meio de obtenção de prova ou meio de prova, a colaboração "não vale como prova incriminatória. E se outras existem, a condenação será uma resultante delas e não da chamada do co-réu” (2008, p. 136).

Em que pese o posicionamento exortado, são latentes, ainda, as divergências doutrinárias a respeito da natureza jurídica e do valor probatório da delação premiada.

No entanto, depreende-se da maior parte da doutrina em exame que a colaboração processual é, efetivamente, dotada de valor probatório, desde que corroborada por outros elementos de prova reunidos no processo penal e submetida ao contraditório e à ampla defesa.

\section{DOS PROBLEMAS QUE GRAVITAM EM TORNO DA DELAÇÃO PREMIADA: A (IN)CONSTITUCIONALIDADE E A QUESTÃO ÉTICA}

A constitucionalidade da delação premiada é tema por demais tortuoso. Jacinto Nelson de Miranda Coutinho assim analisa a delação premiada:

Inconstitucional desde a medula, a sua prática, dentro de um sistema processual penal de matriz inquisitória, ofende $1^{\circ}$ ) o devido processo legal; $2^{\circ}$ ) a inderrogabilidade da jurisdição; $3^{\circ}$ ) a moralidade pública; $4^{\circ}$ ) a ampla defesa e o contraditório e $5^{\circ}$ ) a proibição às provas ilícitas. Só isso, então, já seria suficiente para que se não legislasse a respeito e, se assim não fosse, que se não aplicasse. (COUTINHO, 2006, p. 7-9).

Em sentido antagônico, Frederico Valdez Pereira (2013, p. 87) defende que apenas se poderia considerar inconstitucional o instituto da delação se o direito do delator a não confessar fosse elevado à categoria de irrenunciável, ou ainda, se aceito como 
voluntariamente renunciável, que a premiação pela colaboração eliminasse de plano o requisito de voluntariedade, o que, contudo, não se verifica na hipótese.

Marcos Paulo Dutra Santos (2017, p. 78), por sua vez, advoga a constitucionalidade do instituto premial, aduzindo que "a opção pela colaboração [...] é um dos caminhos que o acusado pode eleger, logo, enquanto tal, é manifestação da ampla defesa".

Ao enfrentar a questão, o Pleno do Supremo Tribunal Federal reconheceu, em 27 de agosto de 2015, à unanimidade, a constitucionalidade da colaboração premiada, quando do julgamento do HC 127.483/PR, relacionado à Operação "Lava Jato" (SANTOS, 2017, p. 81).

Já quanto à celeuma ética que gira em torno da delação como instituto probatório, sobretudo em face da legitimação da traição pelo corréu delator contra seu comparsa delatado, merece destaque o entendimento esposado pelo então juiz federal Sérgio Fernando Moro, que comandava a "Operação Lava Jato" no Brasil. Ao tecer breves considerações acerca da Operação "Mani Pulite”, realizada na Itália, Moro registrou que:

Um criminoso que confessa um crime e revela a participação de outros, embora movido por interesses próprios, colabora com a Justiça e com a aplicação das leis de um país. Se as leis forem justas e democráticas, não há como condenar moralmente a delação; é condenável nesse caso o silêncio (MORO, 2004, p. 58).

Nessa lógica, avulta-se forte e instigante o dilema ético em face da delação premiada, haja vista que, se por um lado aquele que fulmina a confiança do fidedigno comparsa de empreitada(s) ilícita(s) é moralmente repudiável, por outro lado o silêncio do infrator, ou seja, daquele que muito sabe e pode esclarecer acerca do(s) crime(s) apurado(s), é também condenável, por se deixar de colaborar com a justiça e de homenagear a aplicação da lei.

Por derradeiro, Damásio de Jesus (2005, p. 53) afirma a respeito do tema: “a polêmica em torno da 'delação premiada', em razão de seu absurdo ético, nunca deixará de existir. Se [...] representa importante mecanismo de combate à criminalidade organizada, [...] parte traduz-se num incentivo legal à traição".

\section{CONSIDERAÇÕES FINAIS}

Rev. do Cejur: Prestação Jurisdicional, Florianópolis v.7 n.1, p.39-60, Janeiro-Dezembro. 2019. 
A delação premiada chegou ao Brasil, tal qual na Itália e nos Estados Unidos da América, com a precípua finalidade de conter o crescimento da criminalidade organizada, de forma a representar uma mudança no trato da política criminal. Todavia, o instituto de direito premial foi introduzido no ordenamento jurídico brasileiro de forma assistemática, sem que o legislador tenha tomado qualquer cautela a fim de uniformizar a matéria, dando margem à latente insegurança jurídica.

Os resultados obtidos com o estudo levado a efeito no presente artigo sugerem que a delação premiada possui natureza jurídica de negócio jurídico processual, qualificado expressamente pela lei como meio de obtenção de prova, na esteira do assentado pelo Supremo Tribunal Federal no HC 127.483/PR.

É possível a conclusão, ademais, de que a colaboração processual pode, efetivamente, vir a ser utilizada para embasar a condenação de terceiros, desde que respeitados os pressupostos legais e garantias constitucionais dos envolvidos e contanto que, observada a regra de corroboração, encontre-se respaldo nos demais elementos de prova reunidos.

Nesse rumo, é de se afirmar que à delação premiada somente poderá ser atribuído valor probatório legal se submetida ao contraditório e à ampla defesa no curso do processo em que se apura a responsabilidade do agente delatado, sob pena de nulidade da prova.

Verifica-se que existem questionamentos éticos e morais acerca da delação premiada, bem assim a respeito de sua constitucionalidade, visto que o Estado, utilizando-se das palavras de um traidor, passa a permitir que o instituto em comento sirva, efetivamente, de meio de obtenção de prova para embasar a condenação do comparsa delatado.

Não obstante, conclui-se que a delação premiada possui valor probatório no processo penal brasileiro, em face do reconhecimento de sua constitucionalidade pelo Supremo Tribunal Federal no HC 127.483/PR e de sua admissibilidade legal.

\section{REFERÊNCIAS}

ARANHA, Adalberto José Q. T. de Camargo. Da prova no processo penal. 7. ed. São Paulo: Saraiva, 2008. 
BADARÓ, Gustavo. O valor probatório da delação premiada: sobre o $\S 16$ do art. $4^{\circ}$ da Lei $\mathrm{n}^{\circ}$ 12.850/13, Consulex: revista jurídica, Brasília, v. 19, n. 443, fev. 2015, p. 26-29.

BONFIM, Edilson Mougenot. Curso de processo penal. 10. ed. São Paulo: Saraiva, 2015.

BRASIL. Constituição da República Federativa do Brasil de 1988. Disponível em: http://www.planalto.gov.br/ccivil_03/constituicao/constituicao.htm. Acesso em: 11 out. 2017.

Decreto-lei $\mathrm{n}^{\circ} 3.689$, de 3 de outubro de 1941. Código de Processo Penal. Disponível em: http://www.planalto.gov.br/ccivil_03/decreto-lei/Del3689Compilado.htm. Acesso em: 11 out. 2017.

Lei $\mathbf{n}^{\circ}$ 8.072, de 25 de julho de 1990. Dispõe sobre os crimes hediondos, nos termos do art. $5^{\circ}$, inciso XLIII, da Constituição Federal, e determina outras providências. Disponível em: http://www.planalto.gov.br/ccivil_03/leis/L8072.htm. Acesso em: 12 out. 2017.

Lei $\mathbf{n}^{0}$ 9.807, de 13 de julho de 1999. Estabelece normas para a organização e a manutenção de programas especiais de proteção a vítimas e a testemunhas ameaçadas, institui o Programa Federal de Assistência a Vítimas e a Testemunhas Ameaçadas e dispõe sobre a proteção de acusados ou condenados que tenham voluntariamente prestado efetiva colaboração à investigação policial e ao processo criminal. Disponível em: http://www.planalto.gov.br/ccivil_03/leis/L9807.htm. Acesso em: 12 out. 2017.

Lei $\mathbf{n}^{\circ}$ 12.850, de 2 de agosto de 2013. Define organização criminosa e dispõe sobre a investigação criminal, os meios de obtenção da prova, infrações penais correlatas e o procedimento criminal; altera o Decreto-Lei no2.848, de 7 de dezembro de 1940 (Código Penal); revoga a Lei no 9.034, de 3 de maio de 1995; e dá outras providências. Disponível em: http://www.planalto.gov.br/ccivil_03/_ato20112014/2013/lei/112850.htm. Acesso em: 13 out. 2017.

Supremo Tribunal Federal. HC 127.483. Relator(a): Min. Dias Toffoli, Tribunal Pleno, julgado em 27/08/2015.

COUTINHO, Jacinto Nelson de Miranda. Fundamentos à inconstitucionalidade da delação premiada. In: Boletim do IBCCRIM, ano 13, n. 159, fevereiro de 2006, p. 7-9.

DELMANTO, Roberto; DELMANTO JUNIOR, Roberto; DELMANTO, Fabio M. de Almeida. Leis penais especiais comentadas. 2. ed. São Paulo: Saraiva, 2014.

DIPP, Gilson. A “delação" ou colaboração premiada: uma análise do instituto pela interpretação da lei. Brasília: IDP, 2015.

GONZALEZ, Ana Lúcia Stumpf. A Delação Premiada na Legislação Brasileira. 2010. 94p. Trabalho de Conclusão de Curso (Graduação em Direito) - Universidade Federal do Rio Grande do Sul, Porto Alegre. 2010.

JESUS, Damásio E. de. Estágio atual da "delação premiada" no direito penal brasileiro. Revista Jus Navigandi, ISSN 1518-4862, Teresina, ano 10, n. 854, 4 nov. 2005. Disponível em: https://jus.com.br/artigos/7551. Acesso em: 22 out. 2017. 
LIMA, Renato Brasileiro de. Manual de Processo Penal. 3. ed. revista, ampliada e atualizada. Salvador: JusPODIVM, 2015.

LOPES JR., Aury. Direito Processual Penal. 12. ed. São Paulo: Saraiva, 2015.

ROSA, Alexandre Morais da. Como flutua o valor probatório no processo penal? Revista Consultor Jurídico, $1^{\mathrm{o}}$ de setembro de 2017. Disponível em: https://www.conjur.com.br/2017-set-01/limite-penal-flutua-valor-probatorio-processo-penal. Acesso em: 21 out. 2017.

MORO, Sérgio Fernando. Considerações sobre a operação Mani Pulite. In: Revista CEJ, Brasília, n. 26, p. 56-62, jul./set.2004.

MOSSIN, Heráclito Antônio; MOSSIN, Júlio César O. G. Delação premiada: aspectos Jurídicos. 2. ed. Leme: J. H. Mizuno, 2016.

NUCCI, Guilherme de Souza. Manual de processo penal e execução penal. 11. ed. rev. e atual. Rio de Janeiro: Forense, 2014.

PEREIRA, Frederico Valdez. Valor probatório da colaboração processual (delação premiada). In: Revista CEJ, Brasília, Ano XIII, n. 44, p. 25-35, jan./mar.2009.

Frederico Valdez. Compatibilização constitucional da colaboração premiada. In: Revista CEJ, Brasília, Ano XVII, n. 59, p. 84-99, jan./abr. 2013.

RANGEL, Paulo. Direito processual penal. 23. ed. São Paulo: Atlas, 2015.

SANTOS, Marcos Paulo Dutra. Colaboração (delação) premiada. 2. ed. rev., ampl. e atual. Salvador: JusPODIVM, 2017.

SILVA, Deonísio da. De onde vêm as palavras: origens e curiosidades da língua portuguesa. 17. ed. Rio de Janeiro: Lexikon, 2014. 